UDC: 811.111:378 https://doi.org/10.22190/JTESAP2104601S

Original scientific paper

\title{
INVESTIGATING LEARNER AUTONOMY OF EFL AND ESP STUDENTS AT THE TERTIARY LEVEL: CROSS-SECTIONAL STUDY
}

\author{
Maja P. Stanojević Gocić ${ }^{1}$, Anita V. Janković ${ }^{2}$ \\ ${ }^{1}$ Academy of Technical and Pre-School Vocational Studies Niš, Department Vranje, Serbia \\ ${ }^{2}$ University of Priština in Kosovska Mitrovica, Faculty of Philosophy, Serbia
}

\begin{abstract}
Learner autonomy is a concept developed to reiterate the need for life-long learning that goes beyond the prescribed curriculum and institutional settings. In addition, learner-centered approach shifts the burden of responsibility from teachers to learners, as learners are now obliged to take charge of their learning. In that respect, students at the tertiary level of education are expected to know how to learn, inclusive of what to learn and where to learn. In other words, they should be trained to organize their own learning, control and monitor their progress, and evaluate the results, whereas the current educational settings should be given the task to contribute to the development of learner autonomy that paves the way for life-long education.

The participants in the research are EFL students from the department of English Language and Literature at Faculty of Philosophy, University of Priština in Kosovska Mitrovica, and ESP students from the Academy of Technical and Pre-School Vocational Studies Niš, Department Vranje. A Learner Autonomy Questionnaire developed by Zhang and Li (2004) was administered to measure students' learner autonomy level. The aim of the paper is not only to outline the significance of taking control of one's learning, but also to use certain tools in the EFL classroom that contribute to the process of building learner autonomy, as its pedagogical implication, including language learning strategies, projectbased tasks, reflective journals, etc.
\end{abstract}

Key words: learner autonomy, lifelong-learning, EFL, ESP, pedagogical implications, tertiary education.

\section{INTRODUCTION}

Since teaching and learning a foreign language in the $21^{\text {st }}$ century requires development and adoption of contemporary methods, techniques, and approaches, learner-centered approach has taken over traditional teacher-centered approach, in which the teacher held a central, directive role, while the learners were passive recipients. The focus of attention is now being invested in learners and the ways they learn. Efficient means for language learning are explored, including language learning strategies as tools

Submitted August $1^{\text {st }}, 2021$, accepted for publication August 15 ${ }^{\text {st }}, 2021$

Corresponding author: Maja P. Stanojević Gocić. Academy of Technical and Pre-School Vocational Studies Niš,

Department Vranje, Serbia. E-mail: maja.stanojevic.gocic@akademijanis.edu.rs

(C) 2021 by University of Niš, Serbia | Creative Commons License: CC BY-NC-ND 
that could enhance and facilitate acquisition. It is determined that students differ substantially not only in terms of their language competence, but also in their aptitudes, beliefs, learning styles, motivation level, and that those differences should be considered and covered within institutional settings.

In learner-centered approach, the learner is actively involved in classroom activities, interacting and/or collaborating with the teacher and fellow students, while instruction is adapted to individual differences and/or preferences. In addition, language in use, i.e., language used in real-life situation is practiced within communicative approach to language learning. As a result, developing communicative competence has been promoted as an ultimate goal of English Language Teaching (ELT). Consequently, language learners are being prepared for the process of life-long learning, since it is acknowledged that language learning is a continuous process that takes place throughout life. In that sense, they are being prepared to assume the role of autonomous learners.

Learner autonomy, as a process that spreads beyond curricular activities, the concepts of self-directed language learning, self-regulation and metacognition, as an umbrella term for metacognitive strategies and metacognitive awareness, became a wellknown concept in modern education. Accordingly, learner autonomy implies that students are expected to know how to learn and when to learn, and to take responsibility for their learning, while the role of a teacher is to foster autonomous learners. In that regard, Cotterall and Crabbe $(1992,11)$ reiterate that autonomous language learning offers important advantages over teacher-dominated language learning, being, “principally philosophical (learners' ownership of the problem), pedagogic (the quality of learning during the course is improved and learners can continue learning independently after the course, and practical (teachers cannot hope to address individual needs without making the process more learner-centered)".

\section{LEARNER AUTONOMY}

The concept of learner autonomy, as one of the concepts in Second Language Acquisition (SLA), in its broadest sense is associated with decision making process and the attitude of taking responsibility. Likewise, investigation of language learning strategies has a prominent role in the theory of SLA. Therefore, autonomous learners should be able to take charge of their learning, i.e., organize, regulate and plan it themselves. In addition, they should know how to learn, when to learn, and what to learn, while learning strategies emerge as one of the most prominent features of an autonomous learner.

Since it is a highly complex concept, several definitions emerged. In that sense, Little $(1991,3)$ defines autonomy as a universal capacity "for detachment, critical reflection, decision-making, and independent action." Ikonen (2013, 10-11) stresses that autonomy as a potential or an ability residing in the learner comprises several versions. The technical version, as a positivist approach to knowledge, entails technical skills, such as learning strategies and task implementation, needed in managing one's own learning. Due to the technical nature of these skills, they can be taught, and presumably promoting the technical version of autonomy in education is rather simple. The psychological version of autonomy, which can be traced to constructivism, refers to learner autonomy as an innate capacity with cognitive aspects, such as attitudes and abilities affecting learning. As an innate capacity that necessitates opportunities to actualize, autonomy can 
either be suppressed or promoted in institutional education. The political version of autonomy, which originates in the critical approaches to language, emphasizes control over the processes and content of learning. It may include determining learning objectives, defining the content and progressions of learning, selecting methods and learning techniques, monitoring the acquisition (rhythm, time, place, etc.), and evaluating the progress (Oxford, 1990; Holec, 1981).

Oxford $(1990,219)$ notices that learner autonomy presupposes self-assessment, as learners are required to evaluate their own progress in order to plan their learning activities. They are entitled to discover and use assessment criteria. Furthermore, asserts learner self-direction differs from autonomy since it implies learning mode, situation, or techniques associated with the responsible attitude (Oxford, 1990, 238-239).

As autonomous learners determine the content of learning (Benson, 2001, 49), they not only decide when to learn and how to learn, but also what to learn, and where to learn, how they think about and manage their learning (Cotterall, 2008, 111). Hence, there are three levels of autonomous learning process: methodological, psychological, and content (political and social element) (Cotterall, 2008, 112).

Learner autonomy is fostered within learner-centered approach. In that regard, Ajideh $(2009,165)$ explains that learner-centeredness is one of the tendencies that support autonomous language, such as courses in which the students have some degree of control, e.g., giving students' freedom to choose materials or giving students some control over their learning process, puts some of the decision making and responsibility in their hands, builds independence and self-reliance.

\section{TOOLS FOR DEVELOPING LEARNER AUTONOMY}

While students' progress from interdependence to independence in language learning, language learning strategies, project-based learning (PBL), and reflective journals, as student-centered type of learning, are deemed as useful tools for developing learner autonomy.

PBL is an innovative approach that develops a multitude of strategies critical for success in the global world, creating technologically skilled and proficient communicators, and advanced problem solvers (Bell, 2010) Project-based work, as a part of PBL, is not classroombased, because students work in relatively small, collaborative groups to achieve common objectives applicable to real-life situations. It challenges students to solve different interdisciplinary problems, helps them build their critical thinking and language competence. In that sense, Díaz Ramírez (2014) has investigated developing learner autonomy through an English for Specific Purposes (ESP) project work of Colombian environmental engineering undergraduates. The results showed that learner autonomy could be developed through cooperative work, in which the students achieved common interests by supporting each other, and displayed self-regulation in regard to facing failures through learning strategies utilized to meet a learning objective.

The term language learning strategies, a sub-category of general learning strategies, has been widely exploited since the seventies, primarily referring to second or foreign language learning. Language learning strategies are viewed as specific steps, behaviors, activities, or procedures students take in order to perform various learning tasks and solve problems they encounter. They can facilitate information transfer from short-term to 
long-term memory. Accordingly, Oxford (1994) explains that language learning strategies are specific actions, behaviors, steps, or techniques students consciously utilize to improve their progress in apprehending, internalizing, and using the second language (Oxford, 1990), as well as tools for active, self-directed involvement needed for developing second language communicative ability (O'Malley \& Chamot, 1990). Namely, the studies in the seventies, produced the list of strategies presumed to be essential for "good L2 learners". They were based on the idea that the success in language learning stem from the deployment of different learning strategies, in addition to communicative competence.

O'Malley and Chamot $(1990,1)$ assert that strategies are special thoughts and actions people use for understanding, learning and memorizing new information, while Cohen $(1998,4)$ defines language learning strategies as processes consciously selected by learners, or actions taken to enhance the learning or use of a second or foreign language by means of storage, retention, recall and application of information about the language.

As research has shown that the conscious, tailored use of such strategies is related to language achievement and proficiency (Oxford, 1994). Students generally use language learning strategies in order to improve their communicative competence.

The most influential questionnaire for investigating language learning strategies is Strategy Inventory for Language Learning (SILL) created by Rebecca Oxford (1990). It encompasses the use of cognitive, metacognitive, affective, social and compensation strategies. While cognitive strategies refer to mental operations, metacognitive strategies help learners to plan, regulate, organize, monitor and assess the learning process. As a result, raising students' metacognitive awareness is crucial for their attainment.

Cotterall $(2008,119)$ stresses that the teacher should pay attention to individual learners, their unique motivations, experience, stories and attitudes, and the like, as an autonomy-fostering approach to language learning is "likely to focus first on individual learners' psychological relation to the language learning process, and only then on the strategies they adopt."

Almusharraf (2019) has explored EFL students' perceptions and applications of autonomous learning strategies for the purpose of English vocabulary development, and the findings showed that students believed that promoting learner autonomy could productively increase their vocabulary learning development and language learning. The results also showed that EFL learners are willing and capable of taking responsibility for their learning, but they are not necessarily encouraged by the teachers to do so. According to this author, the student-centered classroom, where students are posing questions, answering them, taking notes, and working individually and in groups can produce higher level of interaction and productivity. Moreover, Nematipour (2012) has revealed that visual and auditory learning styles positively correlate with learner autonomy in his study of 200 EFL Iranian learners.

In addition, developing pedagogy for autonomy, which has recently risen to prominence as a relevant ELT goal, can produce numerous benefits. In that respect, a 'weak version' of pedagogy for autonomy implies top-down strategy training, assuming that students lack autonomy, while A 'strong version' of pedagogy for autonomy entails recognizing, engaging with, exercising and developing students' existing autonomy (Smith, 2003).

Reflective journals (diaries, logs) could also serve as useful tools for fostering learner autonomy as they can help learners develop metacognitive awareness and self-regulation. They can be organized in a form of a notebook or pieces of paper where learners provide personal accounts of their educational experience, or write down about positive or negative learning experiences, and what they learnt from that experience, errors difficulties and past. It 
offers benefits for both students and teachers, who are, in turn, provided with adequate feedback information.

\section{THE STUDY}

The aim of the study was to map the self-perceptions of the EFL and ESP students of their autonomy level as language learners. The subjects of the investigation were the EFL students of the Department of English Language and Literature at the Faculty of Philosophy ( $\mathrm{N}=47)$ and the ESP students from various departments of the Academy of Technical and Pre-School Vocational Studies in Vranje $(\mathrm{N}=32)$. Their ages range from 19 to 25 years old; 48 were male and 31 were female. The convenience sampling technique was used to collect data due to the COVID-19 constraints. It means that this study took into account all those students who were easily available. The authors submit to the low generalizability of this technique.

For the purposes of this study, A Learner Autonomy Questionnaire developed by Zhang and Li (2004) was administered to the respondents in paper and electronic form (via Google Forms) ${ }^{1}$. The instrument is divided in three parts: a) demographic data on respondents' age, gender, and where they study; b) 11 statements to be marked on the five-point Likert scale intended to measure the frequency of certain actions which reflect learner autonomy; and c) nine multiple-choice statements aimed at further mapping the level of autonomy of the respondents. For the purposes of this paper, we acknowledge the internal consistency for the overall questionnaire (Cronbach' $\alpha .85$ ) as reported by the author of the instrument (Zhang \& Li, 2004). The collected responses were analyzed by means of the descriptive statistical analysis.

\section{DISCUSSION OF RESULTS}

A description and analysis of the results are provided to identify the self-perceptions of the EFL and ESP students of their autonomy level as language learners. Based on the questionnaire administered, as shown in Table 1, regarding the median score of the participants' autonomy questionnaire, the mean score of the EFL learners is 67.5082 with a standard deviation of 6.32283 , meanwhile their scores range from 54 to 81 . The average score of the ESP students is 68.7403 with the standard deviation of 4.25867 , and their scores vary from 64 to 73 . Though, the ESP students exhibit a higher degree of autonomy, it is worth noting that the EFL group is larger by 30 percent and less coherent (min-max range is 54 to 81). Also, the dispersion of the data is higher in the EFL sample. However, the coefficient of variation is very low $(\mathrm{CV}=0.09366)$ so the distribution is more centered than expected.

\footnotetext{
${ }^{1}$ The questionnaire is available here: https://forms.gle/Mb3FbEAUtfkzdiFM7
} 
Table 1 Descriptive Statistics on Autonomy Scores Based on Language Learning Profile (EFL or ESP)

\begin{tabular}{|c|c|c|c|c|c|}
\hline Autonomy & $\mathrm{N}$ & Min & Max & Mean & SD \\
\hline EFL & 47 & 54.00 & 81.00 & 67.5082 & 6.32283 \\
ESP & 32 & 64.00 & 73.00 & 68.7403 & 4.25867 \\
\hline
\end{tabular}

In order to take a deeper look into the different attitudes and behaviors that reflect learner autonomy, we broke down the responses to individual items in the two major parts of the questionnaire (B and $\mathrm{C}$ ). For the purpose of presenting the results economically, the two highest/lowest values will be merged - the sum of the responses 'often' and 'always' / 'never' and 'rarely'. Chart 1 shows the data distribution for the 11 statements in Part B to be marked on the five-point Likert scale intended to measure the frequency of certain actions which indicate autonomy. Over 70 percent of the respondents believe they have the ability to learn English. The items exploring the time management skills show less coherence in responses (questions 2 and 4). Namely, most of the respondents believe that they make a good use of their spare time ( 0 responses on the lower end of the scale), though ten percent of them indicated that they have poor time management skills.

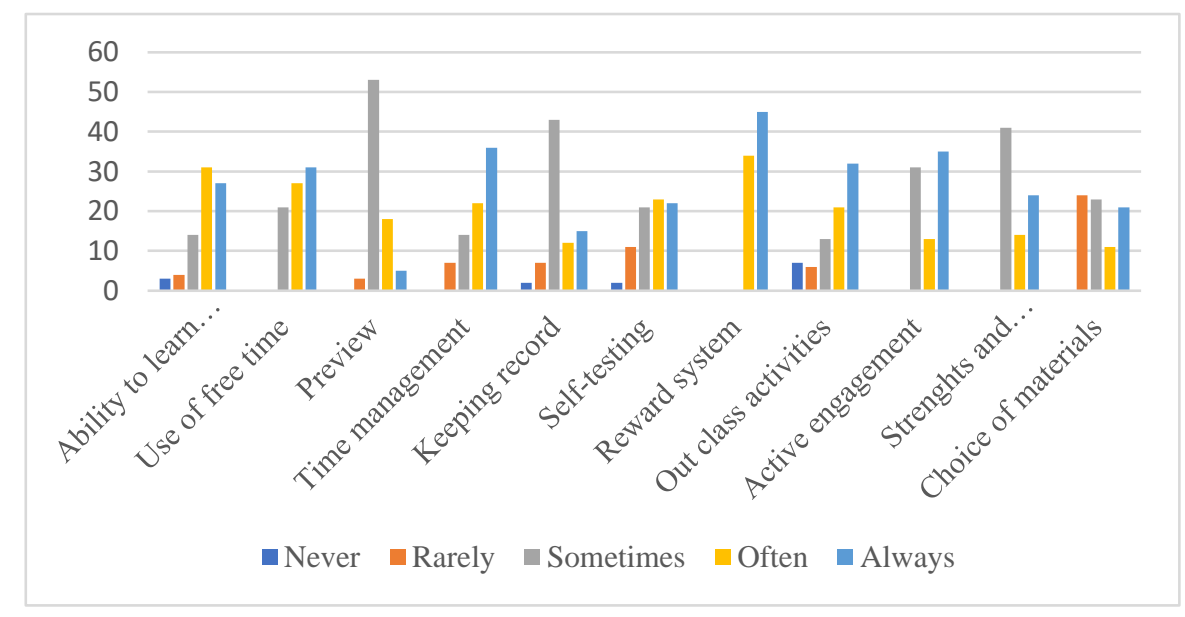

Chart 1. Part B of the Questionnaire

Another aspect of autonomy is keeping record and reward system for one's progress (questions 5 and 7). Only 50 percent of the respondents keeps track of their own progress, while everyone rewards themselves when they achieve success which is unlike what Nematipour (2012) reported. Results showed low autonomy in the aspects of preview, self-testing, and choice of the materials (questions 3, 6, and 11). Namely, over 50 percent of the respondents only sometimes preview the lessons, less than 40 percent self-test themselves or choose their own learning material. As much as 15 percent of the students reports no opportunity to practice language use outside of class while a great majority takes every opportunity in class for engagement (questions 8 and 9). Finally, most of the students are aware of their own strengths and weaknesses (question 11). Bearing all this in mind, the lack of self-discipline combined with poor time management might negatively 
affect that individual work time outside of class, and consequently hinder their learner autonomy, as found by Buendía Arias (2015).

The break-down of Part $\mathrm{C}$ of the questionnaire (Chart 2) provides a clearer insight into the level of learner autonomy of the respondents. The students believe that the teacher-student relationship (question 12) is that of a giver-receiver (32\%) and directorexplorer $(54 \%)$ showing a degree of dependence on the teacher as authority and resource. Furthermore, this is reflected in the fact that as much as $40 \%$ of the respondents place their success or failure into the hands of the teacher (question 13). They also depend on their teachers to correct their mistakes (question 17) and select the learning materials (question 20), also reported by Almusharraf (2019).

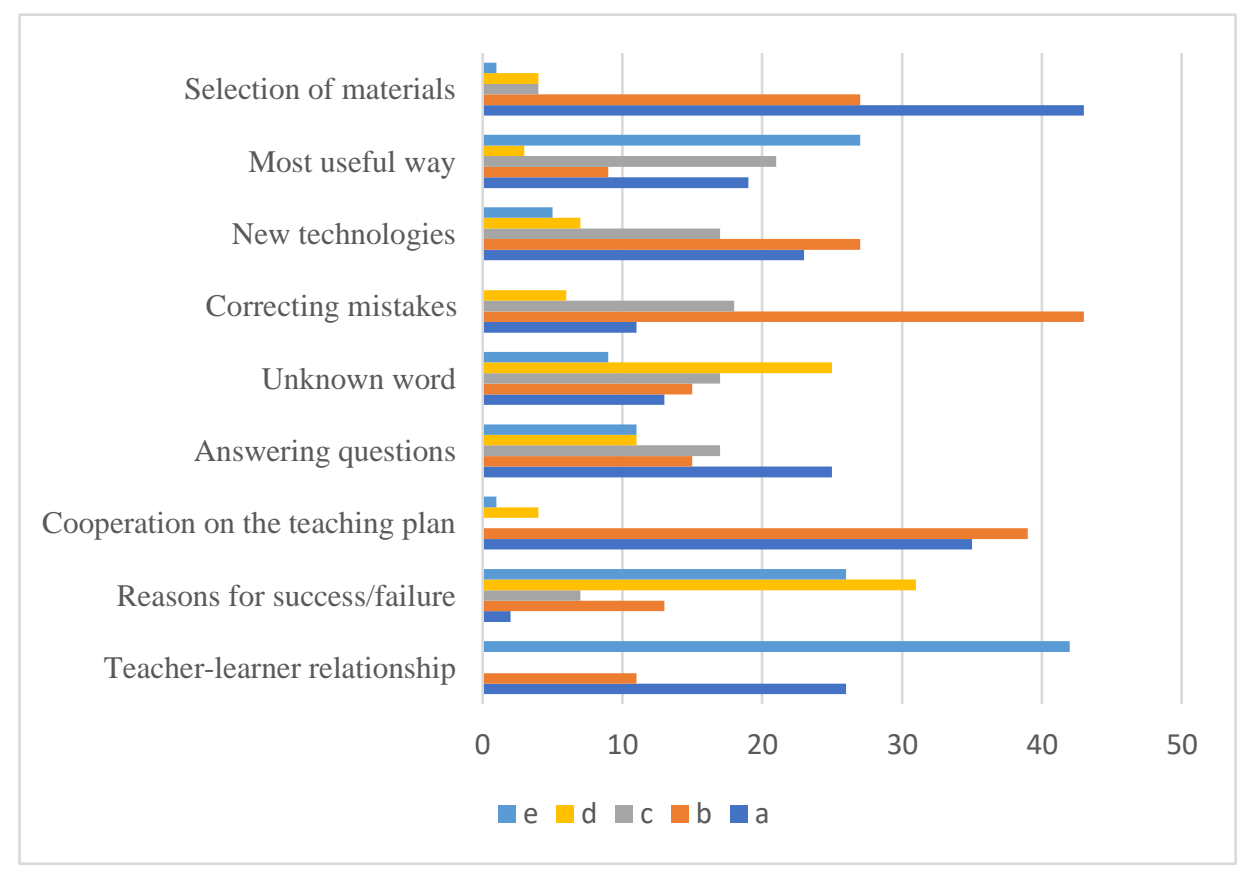

Chart 2. Part C of the Questionnaire

On the other hand, the respondents believe that the curriculum should be a matter of agreement between teachers and students (question 14). In alignment with Nematipour's findings (2012), they preferred pair and group work (question 19) and try to learn on their own or by example when presented with new technologies (question 18). Finally, when encountering a new word (questions 16) they use all resources at their disposal, but 30 percent of them tend to hide behind the rest of the class when a teacher asks a question (question 15).

In summary, this study aimed at a cross-sectional view of the self-perceived autonomy levels of the EFL and ESP students (total N=79). The overall mean value of 3.414 lends itself to the conclusion that most of the respondents exhibit moderate level of autonomy. However, the ESP students show a higher degree of autonomy, while the EFL group is less coherent with the higher dispersion of the data. Several limitations to this study need to be 
acknowledged. Firstly, the sampling technique seriously hinders the generalizability of the survey results. Secondly, the current research was not specifically designed to evaluate factors related to sample demographic or their academic achievement. Furthermore, it is recommended to correlate these findings to those of an earlier study (Stanojević Gocić \& Janković, 2019) which investigated the prefered learning strategies on a similar sample. In that study, the participants completed the Strategy Inventory for Language Learning (SILL), version 7.0 (Oxford, 1990). The structure of the sample was the same as that of the sample in this study in terms of age, gender ratio, field of study, and language learning profile (ESP or EFL) though not necessarily comprised of the same individual students. Finally, despite its exploratory nature, this study offers some practical implications as the results may be used to inform the revision of the instruction practice.

\section{CONCLUSION AND PRACTICAL IMPLICATIONS}

Along with promotion of English as the language of global communication and information spreading, introducing the concept of learner-centeredness, learning styles and strategies, as well as the shift from grammar to communication activities that have vocabulary acquisition as their core element necessary for reading and listening comprehension, insistence on fluency other than accuracy, fostering autonomous learning is of utmost importance in the process of life-long education. In that respect, Ajideh $(2009,165)$ claims that better understanding of the theory would stimulate learners' interest and motivation to practice autonomous learning. Thus, consciousness raising is an important measure to implement this innovation.

In order to foster learner autonomy in EFL class, tools for its development should be integrated in instruction as widely implemented methods. Namely, the importance of project-based task for the development of learner autonomy shouldn't be neglected. Moreover, EFL teachers should incorporate more projects as extracurricular activities that can be implemented to maximize the development of students' language skills. In addition, project-based instruction can also be included in the curriculum.

Since students often use language learning strategies implicitly or subconsciously, strategic instruction, provided by an EFL teacher, would presumably be very useful and beneficial. Students could broaden their repertoire of language learning strategies, as crucial steps for building learner autonomy as research proved that learners who efficiently apply different strategies, such as vocabulary earning strategies, reading strategies, or writing strategies, achieved better results.

Although strategies can be taught both explicitly and implicitly, research show that explicit strategy training is more efficient (Chamot, 2004). Therefore, strategic training (Oxford, 1990), or strategies-based instruction (Cohen, 1998) should be integrated in language instruction. In that sense, students should get acquainted with efficient strategy use, i.e., effective application and combination of different strategies which are useful for the given task through awareness raising. Student would then broaden their repertoire of strategies, practice their implementation, and eventually evaluate the resulting effect within the given strategic model. In that respect, Pavičić Takač $(2008,149)$ insists that today "explicit vocabulary learning strategy training imposes itself as a necessity", inclusive of "raising the learners' awareness of their own strategies, introducing them to 
new ones, and giving them any opportunity to apply, analyze, and adopt new vocabulary learning strategies".

The results of this research could be utilized by the ELT teacher to promote and develop learner autonomy of ELT students, which is prioritized in contemporary methodology and didactics. Therefore, the teacher should introduce the concept of learner autonomy and lead the students towards independent and self-directed learning, development of metacognition and self-regulation, as a general ability to control one's learning.

\section{REFERENCES}

Ajideh, P. (2009). Autonomous Learning and Metacognitive Strategies Essentials in ESP Class. English Language Teaching, 2(1), 162-168.

Almusharraf, N.M. (2019). Learner Autonomy and Vocabulary Development for Saudi University Female EFL Learners: Students' Perspectives. International Journal of Linguistics, 11 (1), 166-195.

Bell, S. (2010). Project-Based Learning for the 21st Century: Skills for the Future. The Clearing House: A Journal of Educational Strategies, Issues and Ideas, 83(2), 39-43.

Benson, P. (2001). Teaching and researching autonomy in language learning. Harlow: Pearson.

Buendía Arias, X. P. (2015). A Comparison of Chinese and Colombian University EFL Students Regarding Learner Autonomy. PROFILE Issues in Teachers' Professional Development, 17(1), 35-53.

Chamot, A. U. (2004). Issues in Language Learning Strategy Research and Teaching. Electronic Journal of Foreign Language Teaching, 1(1), 14-26.

Cohen, A. D. (1998). Strategies in learning and using a second language. London: Longman.

Cotterall, S. (2008). Autonomy and Good Language Learners. In: C. Griffiths (Ed.), Lessons from Good Language Learners, 110-120. Cambridge: CUP.

Cotterall, S. \& Crabbe, D. (1992). Fostering Autonomy in the Language Classroom: Implications for Teacher Education. Guidelines 14 (2), 11-22.

Díaz Ramírez, M. I. (2014). Developing Learner Autonomy through Project Work in an ESP Class. HOW, A Colombian Journal for Teachers of English, 21(2), 54-73.

Holec, H. (1981). Autonomy and foreign language learning. Oxford: Pergamon.

Little, D. (1991). Learner autonomy 1: definitions, issues and problems. Dublin: Authentik.

Ikonen, A. (2013). Promotion of Learner Autonomy in the EFL Classroom: The Students' View. 2013. Master's thesis. University of Jyväskylä Department of Languages English, retrieved from

https://jyx.jyu.fi/bitstream/handle/123456789/42630/URN:NBN:fi:jyu201312102771.pdf?sequence $=1$

Nematipour, M. (2012). A Study of Iranian EFL Learners' Autonomy Level and its Relationship with Learning Style. English Linguistics Research 1(1), 126-136.

O’Malley, J. M., \& Chamot, A. U. (1990). Learning strategies in second language acquisition. Cambridge: Cambridge University Press.

Oxford, R. (1990). Language learning strategies - What every teacher should know. Boston: Heinle \& Heinle Publishers. 
Oxford, R. (1994). Language learning strategies: An update. Washington DC: ERIC Clearinghouse on Languages and Linguistics, Center for Applied Linguistics.

Pavičić Takač, V. (2008). Vocabulary learning strategies and foreign language acquisition. Clevedon, UK: Multilingual Matters.

Posada, J. Z. (2006). Evaluating Students' Autonomous Learning through their Uses of a Self-Access Centre. Colombian Applied Linguistic Journal, 8, 53-73.

Smith, R. (2003). Pedagogy for Autonomy as (Becoming-) Appropriate Methodology. In D. Palfreyman \& R. C. Smith (Eds.), Learner Autonomy across Cultures, 129-146. London: Palgrave Macmillan

Stanojević Gocić, M. \& Janković, A. (2019). Strategy Inventory for Language Learning Cross-Sectional Study. In M. Lončar Vujnović (Ed.), Science Beyond Boundaries II: International Thematic Journal, Bk. 3: Educational Approaches, 175-188. Kosovska Mitrovica: Faculty of Philosophy, University of Priština.

Zhang, L.X. \& Li X.X. (2004). A Comparative Study on Learner Autonomy between Chinese Students and West European Students. Foreign Language World, 4(1), 15-23. 